\title{
Enhanced Performance in High School Electricity Practical: The Micro Electricity Kit Use Versus Conventional Apparatus
}

\author{
Monica Khasandi Mulongo, Amadalo Maurice Musasia, Michieka Ronald Mong'are \\ Department of Science Education, Masinde Muliro University of Science and Technology, Kakamega, Kenya \\ Email address: \\ monitaracha@gmail.com (M. K. Mulongo)

\section{To cite this article:} \\ Monica Khasandi Mulongo, Amadalo Maurice Musasia, Michieka Ronald Mong'are. Enhanced Performance in High School Electricity \\ Practical: The Micro Electricity Kit Use Versus Conventional Apparatus. Science Journal of Education. Vol. 4, No. 4, 2016 , pp. 123-128. \\ doi: 10.11648/j.sjedu.20160404.11
}

Received: July 6, 2016; Accepted: July 13, 2016; Published: July 28, 2016

\begin{abstract}
This study investigated students' performance in electricity practical through the usage of micro electricity kits and conventional laboratory apparatus in Kakamega North sub-county as an intervention mechanism. Specifically the study compared the learners' performance in an electricity practical test by students who used the micro electricity kit and those taught using conventional experimental apparatus. The research design adopted for the study was a two group quasiexperimental randomized pretest-posttest experimental design. A sample size of 537 form two students from fourteen schools were selected by stratified random sampling technique. The experimental group was exposed to the use of micro electricity kits while the control group was conventionally subjected to the same instructional technique. Two performance tests (EPT1 and EPT2) which acted as pre-test (bulbs in series and parallel) and post-test (ohms law) respectively of reliability index 0.74 and 0.87 were administered to both groups at an interval of one month between them. Validity of the instruments was determined with the help of three experienced secondary school teachers at values between 6 and 9 out of 10 for each of them. The obtained data were analyzed according to the hypothesis using both descriptive (means, percentages frequencies tables) and inferential (t-test chi square and anova) statistics. The findings indicated that students who used micro kits performed better than those who used conventional apparatus in electricity practical. Students from county schools performed better than those from sub-county schools. Male students who used the kits performed better than female students. Therefore the kits should be incorporated in the Kenyan school curriculum. These kits can be mainstreamed in physics practical work so as to provide practical experience and conceptual understanding of physics concepts. The government should provide adequate finances, laboratories, apparatus and teachers to sub-county schools so as to compete with the county schools. Physics teachers should also give attention and encourage female physics students during practical sessions such that both male and female students can perform better in the study of physics.
\end{abstract}

Keywords: High School, Electricity, Practical, Micro Electricity Kits, Performance in Electricity Practical

\section{Introduction}

Physics is the science that attempts to describe how nature works. It is often considered the most fundamental of the natural sciences. It is the most basic of sciences and its concepts and techniques lead to the progress of all other branches of science. Its theories attempt to describe the behavior of the smallest building blocks of matter, light, the universe and forces or energies [1]. The term Physics is derived from the ancient Greek word "physis or physike", which means "nature". Knowledge of physics has led to technological development of devices such as television, computers and most household appliances [2]. It therefore has improved people's quality of life by providing knowledge for developing new instruments and techniques.

Physics provides relevant knowledge required for many career advancement and placement in other established and self-made job opportunities. Students of Physics usually possess excellent analytical, quantitative and problem solving skills. They have the ability to synthesize and analyze large 
quantities of data and to present their analysis in understandable forms [3, 4]. A student of physics is trained on how to systematically identify all factors contributing to a problem and work out how those factors interact in order to solve the problem by breaking complex problem to simple solvable entities. "More importantly an increasing number of employers are starting to realize this fact and are looking out to hire physics graduates [5]".

In Kenya, at secondary school level, the topic "Electricity" is taught in a spiral manner. For instance, in form one a student is introduced to the topic "Cells and simple circuits". "Magnetic effect of an electric current" which the students can easily observe from the simple circuits is taught at form two. "Current electricity" where students can measure current using devices is taught at form three while 'Mains electricity' and 'Electromagnetic induction' that are application of electricity are taught at form four. This system helps the learners' progression from simple to the complex concepts. However several problems are experienced.

There is a problem with the way physics is taught. A nationwide research carried out in US between 2008 and 2009 among public and private high schools, showed that less than two thirds of high school teachers felt adequately equipped to use computers and laboratories for instruction [6]. The report postulates that students learn physics concepts best through experience, discovery and process of peer education. Traditional lecture method is the least effective method for teaching physics. However, most teachers rely more on class lectures and less on students' participatory and exploratory activities. The participatory activities include working together more on practical work, discussing ideas in small groups and presenting findings to class [7].

There is a problem with the way "Electricity" is taught at high school. A survey carried out in 1998 in rural schools in the Eastern cape in South Africa whose findings parallels what is observed in the Kenyan local situation, revealed that teachers were unaware of their presentation problems in teaching science, physics being one of them [6]. Another problem is deficiencies in practical skills and conceptual understanding passed on from one generation to the next. Many teachers do not show interest in understanding how new equipment works. They do not read instruments' manual instructions. In one instance a teacher could not assemble a weighing balance [8].

In many cases practical lessons do not have clear meaningful objectives, hence, they degenerate into routine exercises that produce data mainly for calculations or verifying textbook information [9]. For example, a practical lesson such as "Experiment to prove ohms' law" produces data for graphs and calculations, but does not give a clue on how Ohm arrived at or what led him to that law. Whether a practical is done or not, lessons are often statements of facts or 'absolute truths' from textbooks. School laboratories rarely have the resources to challenge such laws, thus a learner is forced to believe and memorize them. Handicaps in schools include; poorly designed and constructed laboratories, lack of equipment to carry out experiments, overcrowding in classrooms that leaves most of the learners watching from a distance [10].

The KNEC 2007 report reveals that there was poor performance in electricity practical question due to faulty measurement, wrong reading and slovenly recording of results among students. The 2010 KNEC report also reveals that many students fail in physics. A major reason given for this is due to drilling by memorizing through repetition of statements rather than from meaningful practical learning. Earlier, efforts had been made in teaching 'electricity' by introducing the topic "Teaching and learning electricity" in the primary and secondary curricula [11].

The practical KCSE physics paper accounts for a major proportion of the overall mark in the subject. Therefore, one cannot perform well in physics when the practical paper is performed poorly. Many of the questions of the practical paper are on electricity (KNEC 2003-2008). According to the KNEC reports the performance in practical paper has been poor with an average score of 19.04 out of 40.0 (KNEC 2007).

A new initiative to bring practical lessons to disadvantaged schools is being carried out by The African Science Truck Experience (TASTE). This is a registered community based organization whose main activity is the operation of mobile science laboratory. It is operational in South Africa, Tanzania, Uganda, Ethiopia, Nigeria and Zimbabwe. It is hoped to spread to other African countries including Kenya. It aims at bringing practical experiments to an interested number of students each year by using a mobile laboratory to visit multiple schools.

\subsection{The Problem}

Practical work plays a central role in learning physics. In Kenyan schools many, students are hardly directly involved in actual hands-on manipulation of equipment and apparatus. Conventional laboratories are expensive to equip, making them expensive to run. The few conventional experiments are routine and rarely make the learners gain insight in the phenomena being interrogated. Large scale practical work is hardly used in many schools due to logistical and cost reasons. One way to go in trying to solve equipment scarcity in schools is by use of micro kits. This study enabled the learners to investigate current electricity phenomena using micro electricity kits. As a result the learners' performance on a practical task was determined. Results from students who used micro kit practical were compared to that by conventional laboratory equipment.

\subsection{Objective of the Study}

The objective of the study was to find out if there is any difference in students' performance in an electricity practical test using micro electricity kits compared to conventional practical equipment. 


\section{Methodology}

\subsection{Research Design}

The research adopted in this study is the Pre-test, Posttest two group quasi experimental design as shown in table 1 below.

Table 1. Research design.

\begin{tabular}{llll}
\hline Group & Pre-test & Treatment & Post-test \\
\hline Experimental & $\mathrm{O}_{1}$ & $\mathrm{X}$ & $\mathrm{O}_{2}$ \\
Control & $\mathrm{O}_{1}$ & $\mathrm{C}$ & $\mathrm{O}_{2}$ \\
\hline
\end{tabular}

The students who used micro electricity kits are referred to as Experimental while those who used the conventional apparatus are the control group.

\subsection{The Sample}

The population of the students consisted of 3534 form two students from Kakamega North sub-county. A stratified sampling technique was used to obtain a sample size of 537 students, 263 boys and 274 girls. The schools were divided into two strata, 4 county and 10 sub-county schools. Four county schools; two control and the other two experimental, ten sub-county schools; five experimental and five control were used. In total 14 schools were used as shown in table 2 below. There were 182 students from county schools and 355 students from sub-county schools. Form two whole classes were used since it is at that level when students select physics as a subject or drop it.

Table 2. Sampling Frame.

\begin{tabular}{llll}
\hline School type & $\begin{array}{l}\text { Total } \\
\text { Population }\end{array}$ & $\begin{array}{l}\text { No. selected } \\
\text { for study }\end{array}$ & $\begin{array}{l}\text { \% of sample to } \\
\text { total Population }\end{array}$ \\
\hline County & 4 & 4 & 100 \\
Sub-county & 36 & 10 & 27.8 \\
Total & 40 & 14 & 35 \\
\hline
\end{tabular}

There were 45 boys and 48 girls, totaling to 93 from county schools that formed the experimental group. While 43 boys and 46 girls totaling to 89 from the county schools formed the control group. 88 boys and 89 girls totaling to 177 from sub-county schools formed the experimental group. While 87 boys and 91 girls totaling to 178 from sub-county schools formed the control group. This comes to a total of 537 students as shown in table 3.

Table 3. Sample Size.

\begin{tabular}{lllll}
\hline \multirow{2}{*}{ School type } & \multicolumn{2}{l}{ Respondents } & & \\
\cline { 2 - 5 } & Group & Girls & Boys & Total \\
\hline \multirow{2}{*}{ County } & Experimental & 48 & 45 & 93 \\
& Control & 46 & 43 & 89 \\
\multirow{2}{*}{ Sub-county } & Experimental & 89 & 88 & 177 \\
\multirow{2}{*}{ Total } & Control & 91 & 87 & 178 \\
\hline
\end{tabular}

The researcher sought formal permission from the ministry of Education through the school of Graduate of Masinde Muliro University. Notification letters to do the research in the selected schools in Kakamega North sub-county was availed to the head teachers. The researcher trained the teachers (assistants) on micro kit use before the actual experiments. The researcher and the assistants collected data. Data was obtained from the practical test which was then used to determine the learner's performance.

The research instruments were two tests which were administered, Experimental test 1 (EPT1) which was done as a Pre-test covering the introductory part of the electricity practical, before teaching. While Experimental test 2 (EPT2) were done as Post-test after teaching. Pre-test consisted of five basic questions on bulbs in series and nine on bulbs in parallel. It is a test for practical work and was administered before teaching with a total score of 10 marks. After one month of instruction, the groups were given a Post-test consisting of nine questions on ohms law with a total score of 20 marks. Figure 1 below shows one of the set up experiment using micro electricity kit.

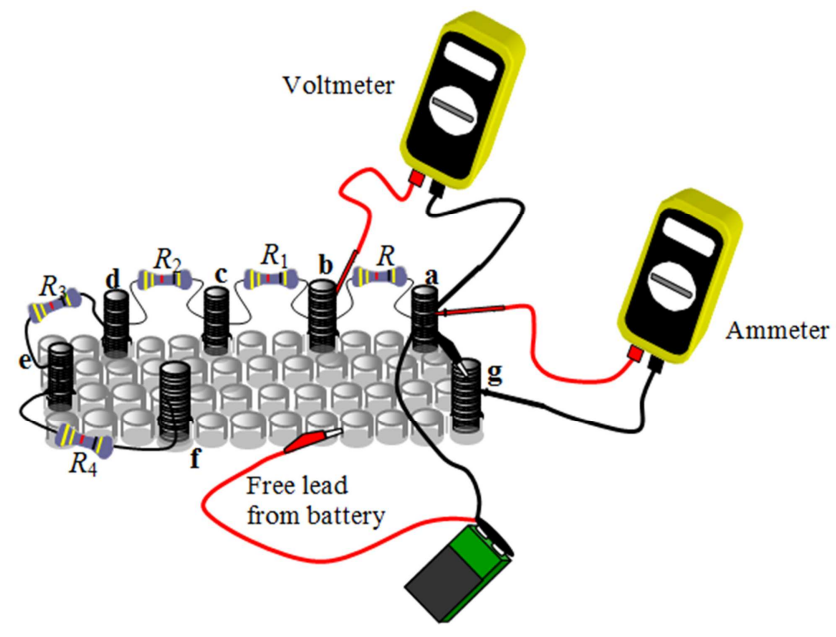

Figure 1. Setup apparatus used in this study.

\section{Results and Discussion}

Pre-test (EPT1) was given one month before Post-test (EPT2) and the results are indicated in table 4 below.

Table 4. Results of group performance on Pre-test and Post-test.

\begin{tabular}{llllll}
\hline & Pre-test & \multicolumn{5}{c}{ Post-test } \\
& Mean & SD & Mean & SD & Gain \\
\hline Experimental & 43.0 & 0.74 & 75.4 & 0.99 & 32.4 \\
Control & 42.2 & 0.88 & 67.7 & 0.96 & 25.5 \\
\hline
\end{tabular}

Key SD: Standard deviation

It can be observed from table 4 that the Pre-test mean scores in both experimental and control groups were lower than those of Post-test, i.e., 43.0 for the experimental 42.2 for control under Pre-test, compared to 75.4 for experimental and 67.7 for control in Post-test. This 
indicates a mean gain of 32.4 by the experimental group. This gain is higher than that of the control group which was 25.5. Since there was a significant difference in achievement in the electricity practical for students who used micro kits compared to those who use conventional apparatus it can be suggested that the micro kit is a better technique than the conventional practical technique.

To further compare the groups, a t-test was performed on the Post-test only. The results are shown in table 5 below.

Table 5. The t-test for overall performance for Post-test scores.

\begin{tabular}{lllll}
\hline Group & Number Respondents $(\mathbf{N})$ & Mean performance & Standard Deviation & t-test $\boldsymbol{\alpha}=\mathbf{0 . 0 5}$ \\
\hline Experimental & 270 & 75.4 & 0.99 & $\mathrm{t}$-critical \\
Control & 267 & 67.7 & 0.96 & $\mathrm{t}=50$ \\
\hline
\end{tabular}

The standard deviations of both groups are low and almost equal showing that the groups were relatively homogeneous. The mean score therefore becomes the differentiating factor. The higher mean score attained by the experimental group suggests that all the students within this group improved in their performance. Therefore, the experimental instructional technique had a positive influence on the entire respondent's performance in the post-test. The calculated t-test value of 50 was higher than the critical value of 4.30 at a confidence level of $5 \%(\alpha=0.05)$. The results indicate that there is a slight difference between the performances of the two groups. Further, the results are not in agreement with the null hypothesis, showing that the introduction of micro kits to the experimental group brought about the positive change observed in their performance.

\subsection{School Type Post-Test Results in Electricity Practical}

The mean scores for students from county and sub-county are indicated in table 6 below.

Table 6. Mean scores for county and sub-county schools on Post-test.

\begin{tabular}{lll}
\hline & \multicolumn{2}{l}{ School type mean performance } \\
\hline Group & County (N=182) & Sub-county (N=355) \\
\hline Experimental groups & 75.5 & 75.4 \\
Control groups & 67.8 & 67.7 \\
\hline
\end{tabular}

The experimental groups registered a higher mean score as compared to control groups in both county and sub-county schools as indicated in table 6 . In the County schools, the experimental group registered a mean score of 75.5 compared to the Control group's mean score of 67.8. In the sub-county schools, the experimental group scored a mean score of 75.4 versus the control group of 67.7. These results indicate that the use of micro kits by the experimental group assisted the learners to perform better than the use of conventional apparatus.

Anova test was done on these results and the outcome shown in table 7 below. It can be observed that the F-Ratio of 23.96 is greater than the F-Critical value of 1.0 for Anova test. Also, the mean scores differ significantly at $5 \%$. This implies that the performance in county and sub-county schools was different. The F-Ratio indicates that the experimental group improved a great deal in performance as compared to the control group due to the introduction of the micro kits to the group.

Table 7. Anova for county and sub-county schools on Post-test.

\begin{tabular}{l|lllll}
\hline $\begin{array}{l}\text { Source of } \\
\text { variation }\end{array}$ & SS & Df & $\begin{array}{l}\text { Mean } \\
\text { Score }\end{array}$ & F-Ratio & F-critical \\
\hline Between groups & 6518.75 & 3 & 2172.9 & 23.96 & 1.00 \\
Within groups & 90.7 & 1 & 90.7 & & \\
Total & 4253.5 & 4 & & & \\
\hline
\end{tabular}

Stepwise t-test was calculated for each of the following groups as indicated in table 8 below. All except two of the ttests are significant $t=28.5,35.5,38.0$ and 55.0 since they are greater than the critical value of 4.30 . This indicated a significant difference in the performance of the tests between the groups (CE- county experimental, CC- county control, SE-sub-county experimental and SC- sub-county control groups).

Table 8. Step wise t-test

\begin{tabular}{lll}
\hline Groups & t-test value & Comment \\
\hline CE VS SE & $2.5^{*}$ & Insignificant \\
CE VS CC & 28.5 & Significant \\
CE VS SC & 35.5 & Significant \\
SE VS CC & 38.0 & Significant \\
SE VS SC & 55.0 & Significant \\
CC VS SC & $3.3^{*}$ & Insignificant \\
\hline
\end{tabular}

The difference in performance can be attributed to the introduction of micro kits to the learners. The exceptional ttest $\mathrm{t}=2.5$ and 3.3 which are both less than 4.30 the critical value, indicate an insignificant difference in performance between county experimental verses sub-county experimental groups and county control verses sub-county control groups. This is as a result of both groups being subjected to the use of micro kits and the use of conventional apparatus respectively.

\subsection{Gender and Achievement in Electricity Practical Test}

The research sought to find out whether achievement on electricity practical test using micro kits and conventional equipment was gender dependent. The boys' and girls' mean scores and standard deviations were calculated and their means recorded in table 9 below. 
Table 9. Mean score and gender achievement.

\begin{tabular}{lllll}
\hline Group & Boys N=263 & SD & Girls N=274 & SD \\
\hline Experimental & 70.0 & 1.8 & 69.8 & 1.8 \\
Control & 62.0 & 1.9 & 61.9 & 2.3 \\
\hline
\end{tabular}

The boys' experimental groups mean 70.0 is higher than the boys' control group 62.0. The experimental boys' standard deviation was 1.8 while it was 1.9 for boys' control group. Girls' experimental group had a higher mean score of 69.8 as compared to that of the girls' control group of 61.9. The standard deviation for experimental group of girls 1.8 was lower than that of girls control group of 2.3. The experimental groups' standard deviations being lower than the control groups' ones indicate that most students in the experimental group had a closer range in marks scored than those of the control group.

Table 10. Anova for gender relationship.

\begin{tabular}{llllll}
\hline $\begin{array}{l}\text { Source of } \\
\text { variation }\end{array}$ & SS & Df & $\begin{array}{l}\text { Mean } \\
\text { Score }\end{array}$ & F-ratio & F-critical \\
\hline Between groups & 5560.0 & 3 & 1853.3 & 97.0 & 1.0 \\
Within groups & 19.1 & 1 & 19.1 & & \\
Total & 5579.1 & 4 & & & \\
\hline
\end{tabular}

F-test was also done to compare the mean scores between and within groups. Table 10 above indicates that the F-ratio $=$ $\mathrm{MSB} / \mathrm{MSW}=1853.3 / 19.1=97.0$, which is greater than the FCritical value, 1.0. Hence mean scores differ significantly at $5 \%$, which indicates that the performance between the boys and girls was different.

Stepwise t-test was calculated on different groups and the results are as shown in table 11 below.

Table 11. Stepwise t-test for gender comparison.

\begin{tabular}{lll}
\hline Groups & t-test value & Comment \\
\hline BE VS GE & $1.0^{*}$ & Insignificant \\
BE VS BC & 36.4 & Significant \\
BE VS GC & 32.4 & Significant \\
GE VS BC & 35.5 & Significant \\
GE VS GC & 131.7 & Significant \\
BC VS GC & $0.4^{*}$ & Insignificant \\
\hline
\end{tabular}

The groups that indicated a more than 4.30 t-test show that there was significance relationship in performance between boys and girls. While the two insignificant t-test relating boys experimental verses girls experimental, boys control verses girls control $\mathrm{t}=1.0$ and $\mathrm{t}=0.4$ respectively indicate that there was no significant difference in performance between the two groups because they are less than 4.30 the critical value. This shows that the boys who used micro kits had a strong performance just same as that of the girls who used micro kits while boys who used conventional apparatus had a weak performance just same as that of girls who used the same. The use of micro kits did improve the performance of girl's in the experimental group; however this performance just matched that of boys in the experimental group. From the above calculations, there is a general indication that there was a correlation between girls' performance and boys' performance.

\subsection{Discussion on Effectiveness of Micro Kits Compared to Conventional Apparatus Achievement}

The findings of this research agrees with Bradley and Vermaak [12] who reported high positive mean values for the African pupils' handling and managing microscale experiments. They felt microscale experiments were beneficial, fun to do and made them enjoy practical work. The results from the current research resonates well with KNEC (2006) which determined that in the national examinations, those students who performed well in practical work also performed well in the final physics examination. Wasanga [13] also found a similar correlation between theory and practical work and understanding of science subjects which leads to improved performance in achievement tests.

The significant difference in performance between county and sub-county schools as shown by their difference in mean scores indicates that county schools have an advantage over sub-county schools in terms of the laboratory facilities, teaching manpower and financial support from the government. The poor performance in sub-county schools has been linked to a shortage of inspirational and well trained physics teachers, inadequate laboratory facilities and the accompanying exposure to practical instruction at junior secondary school level [14]. This confirms that without proper teaching facilities and improved methodology to enable the teachers effectively evaluate their students' understanding and performance in science laboratory work, then the performance will be low [15].

A research carried out by Orukotan and Balogun [16] are in agreement with the observation of this study on gender performance. In their study they found that male students performed better in science than the female students. Fatoba and Aladejana [17] and Raimi and Adeoye [18] also are in agreement asserting that there is a significant difference between the performance of male and female students in science subjects in favour of males

However, the study of Croxford [19] is contrary to the findings of this study as they claim that girls can perform better than their male counterparts because the intellectual potential of girls is an untapped resource for science and technology. McGuire et al [20] persistently disagree with these findings, preferring macro experiments over micro experiments. In contrast, Macmillan [21] found that there was no significant difference in the mean achievement score of male students exposed to practical physics and that of their female counterparts also exposed to practical physics. Aina and Akintule [22] argue that there is no significant correlation between male and female students' performance in physics practical. However, the performance of each gender is independent of each other. 


\section{Conclusions}

Using micro kits in practical work may bring about improved performance in topics from which the practical is derived. The use of micro kits made the learners better their understanding of concepts and stimulate their interest to do experiments and learn science. Experimenting using these kits can be easily done and quickly done ensuring accurate results if appropriately utilized. The study has shown that students who used micro kits performed better than those who used conventional apparatus as they enjoyed setting up apparatus by themselves.

\section{References}

[1] Phatak, O. (2013). Discoveries that gave physics its theoretical foundation. Education journal, 8 (1), 11-19.

[2] Murenzi, M. R. (2006). Physics has a key role in development. Retrieved on $3^{\text {rd }}$ May 2013 from http://www.scidev.net/en/opinions/physics-has-a-key-role-indevelopment.html

[3] Sadler, P. M., \& Tai, R. H. (1997). The role of high school physics in preparing students for college physics. The Physics Teacher, 35, 282-285.

[4] Harry T. (2011). Why college bound students should take physics at high school. Retrieved $7^{\text {th }}$ July 2015 from zttp://faculty.ucr.edu/ leonid/2012_files/Tom_Jobs_2012.pdf

[5] Deloitte report, (2012). A report prepared for the Institute Physics by Deloitte: The importance of physics to the UK economy. IOP Institute of Physics, London.

[6] Ogunniyi, M. B. (1986). Two decades of science education in Africa. Science Education, 70 (2), 111-122.

[7] Area Chair's handbook (2013). Strengthening physics education supporting physics educators. Maryland 20740, American Association of Physics Teachers, One Physics Ellipse College Park. pg 17.

[8] Manzini, S. (2000). Learners' Attitudes towards the Teaching of Indigenous African Science as part of the School Science Curriculum. Journal of the Southern African Association for Research in Mathematics, Technology and Science Education. 4 (1), pg 19-32.

[9] White, R. T. (1996). The link between the laboratory and learning. International Journal of science Education, 15 (5), 591-605.

[10] Muwanga-Zake, J. W. F. (1998). Is science education in crisis?
Some of the problems in South Africa. Science Education. Online at http://www.scienceinafrica.co.za/scicrisis.htm

[11] Duit, R. (1991). Students' conceptual frameworks: Consequences for leaning science. In S. M. Glyn, R. H. Yeany, B. K. Britton (Eds.). The psychology of learning science, New Jersey: Lawrence Erlbaum Associates, Inc., Publishers. PP. 65-85.

[12] Bradley, J. D \& Vermaak, I (1996). Microscale chemistry from an African perspective. Proceedings of the 14th International Conference on Chemical Education. 100-107, Brisbane, Australia. Royal Australian Chemical Institute.

[13] Wasanga P. M., (2009). The role of examination results as a feedback tool: The Kenyan Experience, First READ Global Conference: Developing a Vision for Assessment Systems, September, 30 -October 2, pp 13-15.

[14] Daramola S. O., (1987). Restructuring Science Education Programmes in Nigerian Higher Institutions, Journal of Curriculum and Instruction, 2 (1 \& 2), 235-240.

[15] Hofstein, A. \& Lunetta, V. N. (2003). The laboratory in science education: Foundations for the twenty-first century, Review of Educational Research, 52 (2), 201-217.

[16] Orukotan, A. F \& Balogun, E. M (2001). Providing an effective participation of women in science mathematics and technology in Nigeria through gender responsive education. $42^{\text {nd }}$ Annual conference proceedings of Science Teachers Association of Nigeria. Pg 218-221.

[17] Fatoba J. O \& Aladejana A. L., (2014). Effects of gender on students' attitude to physics in secondary schools in Oyo state, Nigeria, European Scientific Journal, 10 (7), 399-404.

[18] Raimi S. M \& Adeoye F. A. (2006). Gender differences among college students' as determinants of performance in Integrated Science. African Journal of Educational Research, 8 (1\&2), 41-49.

[19] Croxford, L (2002). Gender and national curricular: Shifting Agendas in the UK and Europe. London: Routledge.

[20] McGuire, P, Ealy, J. \& Pickering, M. (1991). Microscale laboratory at the high school level: time efficiency and student response. Journal of Chemical Education, 68 (10), 869-871.

[21] Macmillan, M. J (2013). Effects of practical physics knowledge on students' academic achievement: A Study of Pankshin Local Government Area Plateau State, Nigeria. World Educators Forum. Pg 1-9

[22] Aina, J. K \& Akintunde, Z. T (2013)|. Analysis of Gender Performance in Physics in Colleges of Education, Nigeria. Journal of Education and Practice. 4 (6). 